\title{
Synergistic effect of targeting dishevelled-3 and the epidermal growth factor receptor-tyrosine kinase inhibitor on mesothelioma cells in vitro
}

\author{
GAKU MORIYAMA $^{1,2^{*}}$, MAYA TANIGAWA $^{1 *}$, KOSUKE SAKAI $^{1,2}$, YUSUKE HIRATA $^{1}$, \\ SATOSHI KIKUCHI ${ }^{1}$, YURIKO SAITO ${ }^{1}$, HIROYUKI KYOYAMA ${ }^{1}$, KUNIKO MATSUDA ${ }^{2}$, \\ MASAHIRO SEIKE ${ }^{2}$, AKIHIKO GEMMA ${ }^{2}$ and KAZUTSUGU UEMATSU ${ }^{1}$ \\ ${ }^{1}$ Department of Pulmonary Medicine, Saitama Medical Center, Saitama Medical University, \\ Kawagoe, Saitama 350-8550; ${ }^{2}$ Department of Pulmonary Medicine and Oncology, \\ Graduate School of Medicine, Nippon Medical School, Tokyo 113-8603, Japan
}

Received October 2, 2016; Accepted October 3, 2017

DOI: $10.3892 / \mathrm{ol} .2017 .7382$

\begin{abstract}
It was previously revealed that Wnt signaling is activated in mesothelioma cells. Although epidermal growth factor receptor (EGFR) is expressed in mesothelioma cells, EGFR-tyrosine kinase inhibitors (TKIs) are not effective for mesothelioma treatment. However, in non-small cell lung cancer, the blocking of Wnt signaling has been identified to enhance the anticancer effect of EGFR-TKIs. To confirm the anticancer effect of blocking Wnt signaling in combination with EGFR-TKI treatment in mesothelioma, the present study evaluated the effect of simultaneous suppression of human dishevelled-3 (Dvl-3) expression with Dvl-3 small interfering RNA (siRNA) and of EGFR inhibition with gefitinib on mesothelioma cell viability. Mesothelioma cell lines with and without $\beta$-catenin gene expression were transfected with Dvl-3 siRNA and were cultured with gefitinib, and cell viability, colony formation and cell cycle analyses were performed. Dvl-3 siRNA downregulated the expression of Dvl-3 in mesothelioma cells. The combination of Dvl-3 siRNA with gefitinib acted synergistically to induce concomitant suppression of cell viability and colony formation, suggesting that inhibition
\end{abstract}

Correspondence to: Professor Kazutsugu Uematsu, Department of Pulmonary Medicine, Saitama Medical Center, Saitama Medical University, 1981 Kamoda, Kawagoe, Saitama 350-8550, Japan

E-mail: kuematsu@saitama-med.ac.jp

"Contributed equally

Abbreviations: Dvl, dishevelled; EGFR, epidermal growth factor receptor; GSK3 $\beta$, glycogen synthesis kinase-3 $\beta$; NSCLC, non-small cell lung cancer; siRNA, small interfering RNA; TKI, tyrosine kinase inhibitor

Key words: mesothelioma, Wnt pathway, dishevelled-3, small interfering RNA, epidermal growth factor receptor, epidermal growth factor receptor-tyrosine kinase inhibitor of Wnt signaling by downregulating Dvl-3 with siRNA and inhibiting EGFR with gefitinib leads to significant antitumor effects.

\section{Introduction}

Malignant mesothelioma is an asbestos-associated pleural malignancy that arises from serosal cells and presents a poor prognosis. Statistical surveys conducted by the Japanese Ministry of Health, Labor and Welfare reported that 1,410 fatalities were caused by mesothelioma in 2013 in Japan, double the number of fatalities in 1999 (www.mhlw.go. jp/toukei/saikin/hw/jinkou/tokusyu/chuuhisyu15/dl/chuuhisyu. pdf). Although therapies including surgery, chemotherapy and radiotherapy have been adopted, the prognosis remains poor. Since the combination of an anti-folate reagent, pemetrexed, and cisplatin was demonstrated to prolong survival for longer than cisplatin alone (1), this combination has been frequently used, but its effects remain limited. Second-line therapy for tumor recurrence has not been established. Newer therapies based on an improved molecular understanding of mesothelioma are therefore required.

Wnt signaling, which activates a canonical pathway through $\beta$-catenin, is aberrantly activated in a wide range of tumors (2). Numerous types of tumor, including colon cancer, undergo aberrant activation of this canonical pathway and Wnt may also activate non-canonical pathways (2). Our previous study identified that Wnt signaling is activated in mesothelioma cells, and that blockade of Wnt signaling may be achieved with antibodies against Wnt-1 or -2 , Wnt-1 or -2 small interfering RNAs (siRNAs), or dominant-negative dishevelled (Dvl), leading to suppressed viability or tumorigenesis of mesothelioma cells in athymic mice (3-7). Notably, the mesothelioma H28 cell line exhibits Wnt signal activity, which blocks apoptosis, without expression of $\beta$-catenin, due to a homozygous deletion of the $\beta$-catenin gene and activation of the aforementioned non-canonical pathways (8). Wnt signaling has been revealed to have a crucial function in maintaining cancer stem cells, which are highly resistant to chemotherapy (9). 
The epidermal growth factor receptor (EGFR)-tyrosine kinase inhibitors (TKIs) gefitinib, erlotinib and afatinib are promising anticancer drugs for the treatment of patients with non-small cell lung cancer (NSCLC) with a specific EGFR mutation (10). EGFR has been revealed to be expressed in $68 \%$ of paraffin-embedded mesothelioma specimens (11). However, EGFR-TKIs alone are not effective in the treatment of mesothelioma (12). In NSCLC, tankyrase, an upregulator of the canonical Wnt signaling pathway, has been revealed to protect lung cancer cells from EGFR inhibition (13). Inhibition of $\beta$-catenin with EGFR-TKIs was reported to be able to enhance the anticancer effect or to overcome the resistance to EGFR-TKIs (14-16). In the present study, the effect of suppression of Wnt signaling with Dvl-3 siRNA and of inhibition of EGFR with gefitinib on mesothelioma cell viability were investigated.

\section{Materials and methods}

Cell lines and cell culture. Mesothelioma NCI-H28 (H28), NCI-H2452 $(\mathrm{H} 2452)$ and MSTO-211H $(211 \mathrm{H})$ cell lines [American Type Culture Collection (ATCC), Manassas, VA, USA] were cultured in RPMI-1640 complete medium (ATCC) containing $10 \%$ fetal bovine serum (FBS; ATCC) in a $75 \mathrm{~cm}^{2}$ tissue culture flask in a $37^{\circ} \mathrm{C} 5 \% \mathrm{CO}_{2}$ incubator for 3 days. Medium was changed every 3 days. Once cells had reached $80 \%$ confluence, they were treated with $0.5 \%$ trypsin $/ 0.2 \%$ EDTA solution (Sigma-Aldrich; Merck KGaA, Darmstadt, Germany) and were passaged 1:4.

Western blot analysis. Cells were removed by scraping, washed with TBS [25 mM Tris- $\mathrm{HCl}(\mathrm{pH} 8.0)$ and $150 \mathrm{mM} \mathrm{NaCl}]$ containing $0.1 \mathrm{mM}$ phenylmethylsulfonyl fluoride and centrifuged at $1,000 \mathrm{x}$ g for $5 \mathrm{~min}$ at room temperature. Cells were lysed using mammalian protein extraction reagent (Thermo Fisher Scientific, Inc., Waltham, MA, USA) and were centrifuged at $10,000 \mathrm{xg}$ for $5 \mathrm{~min}$ at $4^{\circ} \mathrm{C}$. Protein concentrations were determined using the Pierce ${ }^{\mathrm{TM}}$ BCA Protein Assay kit (Thermo Fisher Scientific, Inc.). The supernatant was mixed with an equal volume of $4 \%$ SDS-containing 10\% 2-mercaptoethanol. Whole cell lysate aliquots $(20 \mu \mathrm{g})$ were separated on $4-15 \%$ gradient SDS-polyacrylamide gels, subjected to $10 \%$ SDS-PAGE and were electrotransferred onto an Immun-Blot ${ }^{\mathrm{TM}}$ polyvinylidene difluoride membrane (Bio-Rad Laboratories, Inc., Hercules, CA, USA) for protein blotting. Blots were incubated overnight at $4{ }^{\circ} \mathrm{C}$ with antibodies against Dvl-3 (1:1,000; 4D3; cat. no. sc-8027; Santa Cruz Biotechnology, Inc., Dallas, TX, USA), $\beta$-catenin (1:1,000; cat. no. 610153; BD Biosciences, San Jose, CA, USA), EGFR (1:1,000; cat. no. sc-03; Santa Cruz Biotechnology, Inc.), glycogen synthesis kinase-3 $\beta$ (GSK3 $\beta$ ) (1:5,000; cat. no. 9832; Cell Signaling Technology, Inc., Danvers, MA, USA) or phosphorylated (p)-GSK3 $\beta$ (Ser $\left.{ }^{9}\right)(1: 5,000$; cat. no. 5558; Cell Signaling Technology, Inc.), and anti- $\beta$-actin (1:1,000; cat. no. sc-47778; Santa Cruz Biotechnology, Inc.) was used as an antibody for the reference protein. Antigen-antibody complexes were detected using an enhanced chemiluminescence blotting analysis system (GE Healthcare Life Sciences, Little Chalfont, UK).

Transfection with Dvl-3 siRNA.Dvl-3 siRNA (Stealth RNAi ${ }^{\mathrm{TM}}$ ) was prepared by Invitrogen; Thermo Fisher Scientific, Inc. The

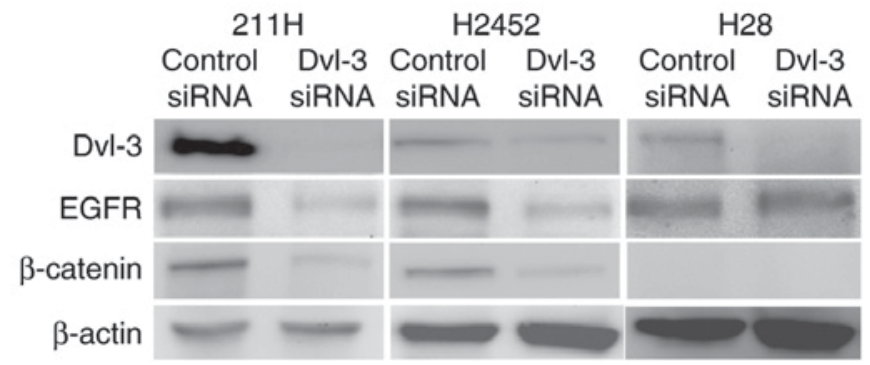

Figure 1. Downregulation of Dvl-3 expression in mesothelioma cells using Dvl-3 siRNA. Western blot analysis revealed that expression of Dvl-3 was downregulated in $211 \mathrm{H}, \mathrm{H} 2452$ and $\mathrm{H} 28$ cells after $48 \mathrm{~h}$ of transfection with Dvl-3 siRNA, compared with cells transfected with control siRNA. $211 \mathrm{H}$ and H2452 cells exhibited expression of EGFR and $\beta$-catenin, whereas $\mathrm{H} 28$ exhibited no $\beta$-catenin expression due to homozygous deletion of the $\beta$-catenin gene. $\beta$-actin served as a loading control. Dvl-3, dishevelled-3; siRNA, small interfering RNA; EGFR, epidermal growth factor receptor.

sequence of the siRNA and the methods of transfection have been described previously (17). Briefly, cells were seeded onto $35-\mathrm{mm}$ dishes at $1 \times 10^{4}$ cells/dish, and were transfected $24 \mathrm{~h}$ later with 4 pmol siRNA using $4 \mathrm{ml}$ Lipofectamine ${ }^{\mathrm{TM}} 2000$ (Thermo Fisher Scientific, Inc.). Cells were then incubated for $24 \mathrm{~h}$ at $37^{\circ} \mathrm{C}$, washed once with PBS, then incubated with RPMI-1640 medium containing $10 \%$ FBS at $37^{\circ} \mathrm{C}$ for $>24 \mathrm{~h}$ for western blot analysis and $>14$ days for colony formation assays on 35-mm dishes, or seeded onto 96-well plates for cytotoxicity assays.

Cytotoxicity assays. Cell viability was assessed using a modification of the MTT assay using the Cell Counting Kit-8 (Dojindo Molecular Technologies, Inc., Kumamoto, Japan) containing 2-(2-methoxy-4-nitrophenyl)-3-(4-nitrophenyl)-5(2,4-disulfophenyl)- $2 H$-tetrazolium and monosodium salt (WST-8) dye. Cells were seeded onto 96-well plates at $5 \times 10^{3}$ cells/well $24 \mathrm{~h}$ after transfection with siRNA. Cell viability was estimated at $24,48,72$ and $96 \mathrm{~h}$ after plating. WST- 8 dye was added $2 \mathrm{~h}$ prior to the end of culture and absorbance was measured at $450 \mathrm{~nm}$ using a Multiskan JX instrument (Thermo Fisher Scientific, Inc.). Experiments were performed $\geq 6$ times. At $24 \mathrm{~h}$ after plating, cells were exposed to 5,10 or $30 \mu \mathrm{M}$ gefitinib (Sigma-Aldrich; Merck KGaA) or dimethylsulfoxide (DMSO) as a control, and cell viability was estimated in the aforementioned manner. Gefitinib was dissolved in DMSO and controls for all experiments were created by adding equivalent volumes of DMSO. Each drug concentration was added to three replicate wells and each experiment was performed 4 times.

Colony formation assays. After $24 \mathrm{~h}$ of siRNA transfection, 400 cells were spread onto $35-\mathrm{mm}$ dishes with RPMI-1640 medium and $10 \%$ FBS, with $5 \mu \mathrm{M}$ gefitinib or DMSO as a control. After 14 days, cells were stained with $0.5 \%$ methylene blue for $24 \mathrm{~h}$ at room temperature and colonies were counted visually. Colony assays were performed $\geq 4$ times and results are reported as the mean.

Cell cycle analysis. After $24 \mathrm{~h}$ of siRNA transfection, $5 \mu \mathrm{M}$ gefitinib or DMSO was added to the medium. A further $24 \mathrm{~h}$ later, cells were collected and a CycleTest PLUS DNA 


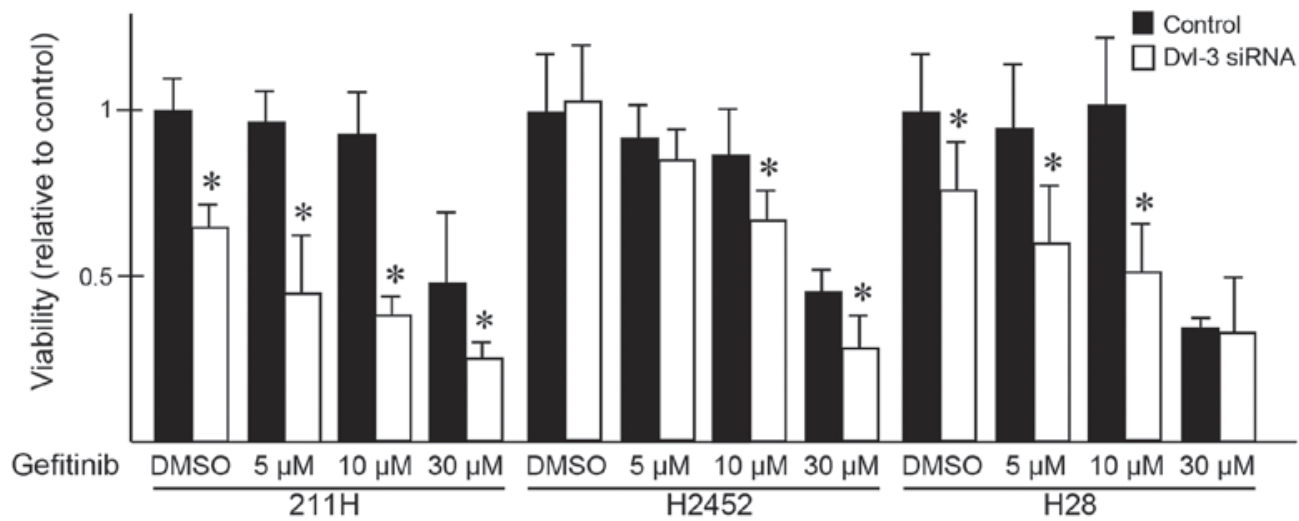

Figure 2. Synergistic suppression of mesothelioma cell viability following treatment with gefitinib and downregulation of Dvl-3. The suppressive effect on cell viability of Dvl-3 siRNA and an EGFR inhibitor, gefitinib, was examined. Cell viability was determined using a Cell Counting Kit-8. The results (ratio of viable cells transfected with Dvl-3 siRNA with or without gefitinib to those transfected with control siRNA and DMSO) at $48 \mathrm{~h}$ after the addition of gefitinib or DMSO are expressed as the mean \pm standard deviation. Cell viability of $211 \mathrm{H}, \mathrm{H} 2452$ and $\mathrm{H} 28$ cells was synergistically suppressed when cells were transfected with Dvl-3 siRNA and treated with gefitinib. Experiments were performed $\geq 6$ times. "P<0.05 vs. control. Dvl-3, dishevelled-3; siRNA, small interfering RNA; EGFR, epidermal growth factor receptor; DMSO, dimethylsulfoxide.

Reagent kit (BD Biosciences, San Jose, CA, USA) was used according to the manufacturer's protocol. Cell cycle analysis was determined using a flow cytometer (BD FACSVerse ${ }^{\mathrm{TM}}$; version 1.0.3.2942; BD FACSuite software; BD Biosciences).

Statistical analysis. Results are expressed as the mean \pm standard deviation. Data between two groups were compared using a two-tailed unpaired Student's t-test. Analysis of variance (ANOVA), followed by Dunnett's test, was used to compare multiple groups. For cytotoxicity assays comparing concentrations of gefitinib, cells treated with DMSO were used as a control and the viability of other cells were compared using ANOVA followed by Dunnett's test. Viability of cells transfected with control siRNA was compared with that of those transfected with Dvl-3 siRNA using a two-sided Student's t-test. $\mathrm{P}<0.05$ was considered to indicate a statistically significant difference. Statistical analysis was performed using a commercial statistical software package (version 21; SPSS Statistics; IBM Corp., Armonk, NY, USA).

\section{Results}

Dvl-3 siRNA downregulates expression of Dvl-3 in mesothelioma cells. Mesothelioma $211 \mathrm{H}, \mathrm{H} 2452$ and $\mathrm{H} 28$ cells express Dvl-3 and EGFR. Whereas H28 cells expressed no $\beta$-catenin due to a homozygous deletion of the $\beta$-catenin gene, $211 \mathrm{H}$ and H2452 cells did. At $48 \mathrm{~h}$ after transfection with Dvl-3 siRNA, expression of Dvl-3 was downregulated in $211 \mathrm{H}, \mathrm{H} 2452$ and H28 cells (Fig. 1).

Downregulation of Dvl-3 and treatment with gefitinib suppresses the viability of mesothelioma cells synergistically. After $24 \mathrm{~h}$ of transfection with Dvl-3 siRNA or control siRNA, gefitinib or DMSO was added to the medium. Following transfection with Dvl-3 siRNA, the viability of H28 and $211 \mathrm{H}$ cells was significantly suppressed compared with that of the cells transfected with control siRNA, but the viability of $\mathrm{H} 2452$ cells was not (Fig. 2). At $48 \mathrm{~h}$ after the addition of gefitinib or DMSO, the viability of $\mathrm{H} 28$ cells transfected with control siRNA was not suppressed in the presence of 5 or
$10 \mu \mathrm{M}$ gefitinib; however, the viability of $\mathrm{H} 28$ cells transfected with Dvl-3 siRNA was significantly suppressed following treatment with these concentrations of gefitinib compared with those treated with DMSO. The viability of $211 \mathrm{H}$ cells was significantly suppressed following treatment with $30 \mu \mathrm{M}$ gefitinib. At 5,10 or $30 \mu \mathrm{M}$ gefitinib, the viability of $211 \mathrm{H}$ cells were significantly suppressed synergistically with Dvl-3 siRNA transfection compared with that of cells transfected with control siRNA. In H2452 cells, 10 and $30 \mu \mathrm{M}$ gefitinib significantly suppressed the viability of cells transfected with Dvl-3 siRNA, compared with that of those transfected with control siRNA.

Downregulation of Dvl-3 suppresses colony formation of mesothelioma cells. Colony counts of $211 \mathrm{H}, \mathrm{H} 2452$ and H28 cells were significantly decreased following transfection with Dvl-3 siRNA, and were further significantly decreased following treatment with $5 \mu \mathrm{M}$ gefitinib, compared with respective controls (Fig. 3).

Downregulation of Dvl-3 and treatment with gefitinib induces G1 population increase. After 48 h of transfection with Dvl-3 siRNA, the population of $211 \mathrm{H}, \mathrm{H} 2452$ and $\mathrm{H} 28$ cells in G1 phase tended to increase (Fig. 4). At a further $24 \mathrm{~h}$ after the addition of gefitinib to the medium, after $24 \mathrm{~h}$ of transfection with Dvl-3 siRNA, the population of $211 \mathrm{H}, \mathrm{H} 2452$ and H28 cells in G1 phase tended to increase further, although these results were not statistically significant ( $P>0.05$; Fig. 4).

Downregulation of Dvl-3 decreases phosphorylation of GSK $3 \beta$. Phosphorylation of GSK3 $\beta$ was decreased in $211 \mathrm{H}$ and H2452 cells following downregulation of Dvl-3 (Fig. 5). In $\mathrm{H} 28$ cells, expression of $\mathrm{p}-\mathrm{GSK} 3 \beta$ and total expression of GSK $3 \beta$ were decreased.

\section{Discussion}

The results of the present study indicate that downregulation of Dvl-3 induced suppression of cell viability and that the addition of the EGFR-TKI gefitinib acted synergistically, 
$211 \mathrm{H}$

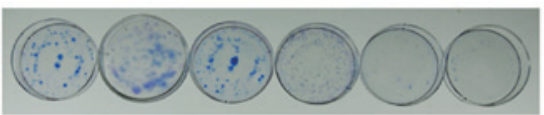

$\mathrm{H} 2452$

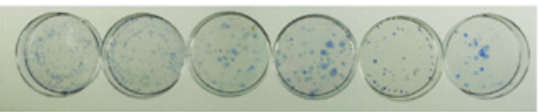

H28

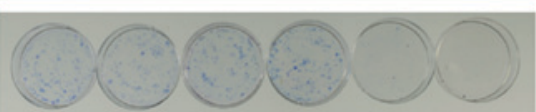

$\begin{array}{lllllll}\text { Control siRNA } & - & - & + & + & - & - \\ \text { Dvl-3 siRNA } & - & - & - & - & + & + \\ \text { Gefitinib }(5 \mu \mathrm{M}) & - & + & - & + & - & +\end{array}$

$211 \mathrm{H}$

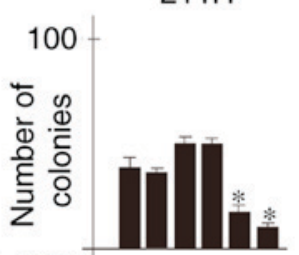

Control siRnA - - + + -

Dvl-3 siRNA ----++

Gefitinib $(5 \mu \mathrm{M})-+-+-+$
$\mathrm{H} 2452$

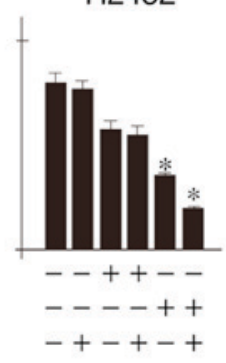

$\mathrm{H} 28$

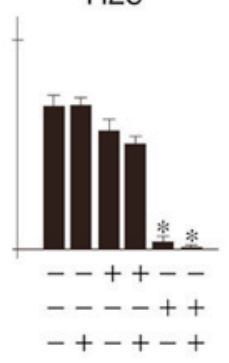

Figure 3. Inhibition of colony formation by downregulation of Dvl-3 and treatment with gefitinib. After $24 \mathrm{~h}$ of transfection with Dvl-3 siRNA, 400 cells were spread onto 35-mm dishes and colonies were counted 14 days later. Colony formation in $211 \mathrm{H}, \mathrm{H} 2452$ and $\mathrm{H} 28$ cells was decreased following transfection with Dvl-3 siRNA, and was further suppressed by treatment with gefitinib, compared with cells transfected with control siRNA and those treated with gefitinib alone. The results of all experiments are expressed as the mean \pm standard deviation. Experiments were performed $\geq 6$ times. ${ }^{*} \mathrm{P}<0.01$ vs. cells transfected with control siRNA. Dvl-3, dishevelled-3; siRNA, small interfering RNA.

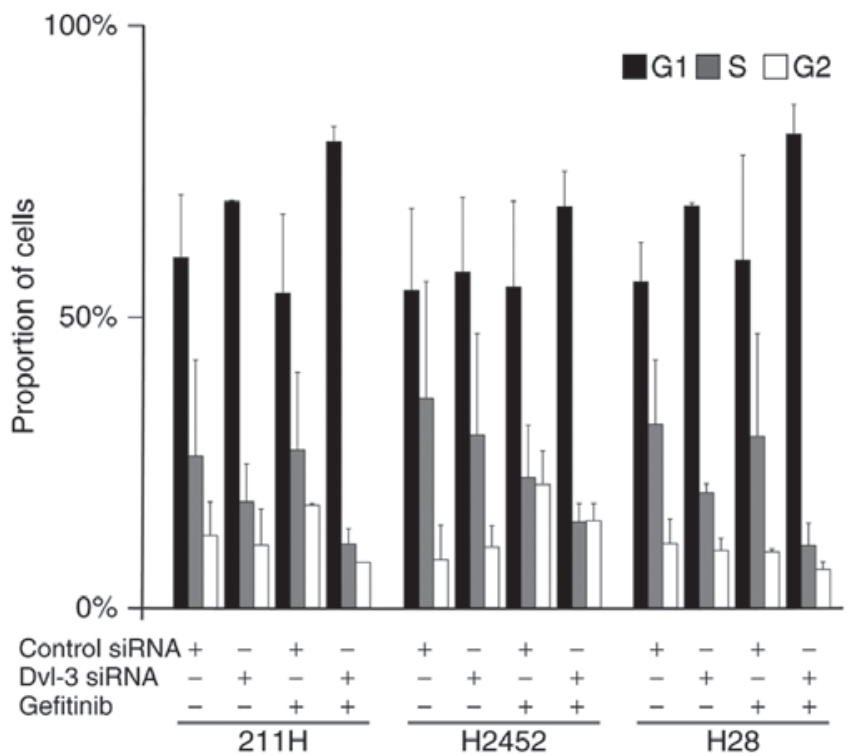

Figure 4. Aberration of cell cycle induced by downregulation of Dvl-3 with gefitinib. Cell cycle aberrations were induced by downregulation of Dvl-3 or transfection with Dvl-3 siRNA combined with treatment with $5 \mu \mathrm{M}$ gefitinib. The proportion of cells transfected with Dvl-3 siRNA and treated with gefitinib in the G1 phase tended to increase, compared with those transfected with control siRNA and those treated with gefitinib alone $(\mathrm{P}>0.05)$. The results of all experiments are expressed as the mean \pm standard deviation. Dvl-3, dishevelled-3; siRNA, small interfering RNA.

resulting in colony formation with a tendency to persist in the G1 phase of the cell cycle. Of all pleural mesotheliomas, $70 \%$ exhibit high levels of EGFR expression (11). Jänne et al (18) demonstrated that $10 \mu \mathrm{M}$ gefitinib suppressed the viability and

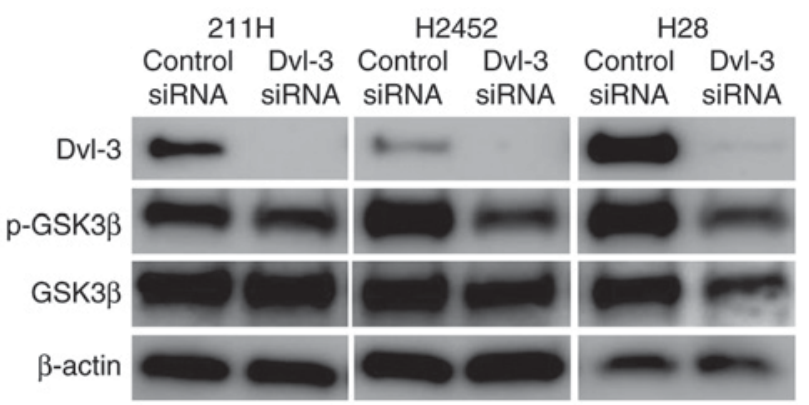

Figure 5. Decrease in phosphorylation of GSK3 $\beta$ following downregulation of Dvl-3. Western blot analysis demonstrated that expression of GSK3 $\beta$ and p-GSK $3 \beta$ whole protein in $211 \mathrm{H}, \mathrm{H} 2452$ and $\mathrm{H} 28$ cells after $48 \mathrm{~h}$ of transfection with Dvl-3 siRNA. $\beta$-actin served as loading control. GSK3 $\beta$, glycogen synthase kinase-3 $\beta$; Dvl-3, dishevelled-3; p-, phosphorylated; siRNA, small interfering RNA.

colony formation of mesothelioma cell lines in soft agarose. It has been demonstrated that $10 \mu \mathrm{M}$ gefitinib exceeds the effective dose in NSCLC (13). In the present study, inhibition of Dvl-3 enhanced inhibition of viability at $10 \mu \mathrm{M}$ in all three mesothelioma cell lines. In $\mathrm{H} 28$ cells, downregulation of Dvl-3 suppressed cell viability, an effect which was enhanced $48 \mathrm{~h}$ after treatment with 5 or $10 \mu \mathrm{M}$ gefitinib. At $30 \mu \mathrm{M}$ gefitinib, H28 cell viability was markedly decreased, but it was not affected by downregulation of Dvl-3. Nutt et al (19) demonstrated that $\mathrm{H} 28$ cell viability was completely suppressed $72 \mathrm{~h}$ after the addition of $30 \mu \mathrm{M}$ gefitinib. A concentration of $30 \mu \mathrm{M}$ gefitinib is more toxic to $\mathrm{H} 28$ cells compared with a concentration of 5 or $10 \mu \mathrm{M}$, and this toxicity may not be associated with signaling pathways affected by the downregulation of Dvl-3. 
The aim of colony formation assay performed in the present study was to investigate the temporary effect of suppression of Dvl-3 combined with treatment with an EGFR-TKI on colony formation of mesothelioma cells. As colony formation was suppressed in the present study, suppression of Dvl-3 may be associated with the initial expansion of cells. A limitation of the present study is that the siRNA had no function after 14 days of transfection. It was confirmed that temporary transfection of siRNA did not suppress Dvl-3 expression after 14 days (data not shown). Future studies are required to examine colony formation using short hairpin RNA in order to elucidate the effect on other signaling pathways of continuous suppression of Dvl-3. In cell cycle analysis, $5 \mu \mathrm{M}$ gefitinib was used, and this dose did not inhibit cell viability effectively $24 \mathrm{~h}$ after the addition. Downregulation of Dvl-3 by siRNA usually induced G1 phase, which tended to be enhanced by gefitinib, although these results were not statistically significant. These results suggest that blockade of the EGF signaling pathway by gefitinib or other EGFR-TKIs, and of Wnt signaling by Dvl-3 suppression may be a useful combination for the treatment of mesothelioma.

p-GSK3 $\beta\left(\operatorname{Ser}^{9}\right)$, which is the inactive form of GSK3 $\beta$ and a regulator of Wnt signaling, and EGFR were revealed to be negatively associated with survival of patients with lung cancer, indicating that EGFR may phosphorylate GSK3 $\beta$ into inactive $\mathrm{p}-\mathrm{GSK} 3 \beta(20)$. GSK $3 \beta$ participates in various critical cellular processes, one of which is the formation of the $\beta$-catenin destruction complex (21). When Wnt signaling is not activated, GSK $3 \beta$ is able to phosphorylate $\beta$-catenin, resulting in its ubiquitination. Dvl family members inhibit activation of GSK $3 \beta$ and degradation of $\beta$-catenin, which is translocated to the nucleus and interacts with transcription factors, resulting in the expression of target genes (21). The results of the present study indicate that downregulation of Dvl-3 decreased phosphorylation of GSK $3 \beta$ in $211 \mathrm{H}$ and $\mathrm{H} 2452$ cells. However, H28 cells without $\beta$-catenin expression exhibited a decrease in $\mathrm{p}-\mathrm{GSK} 3 \beta$ levels and total expression of GSK3 $\beta$ following downregulation of Dvl-3. In $211 \mathrm{H}$ and $\mathrm{H} 2452$ cells, synergistic inhibition of cell viability by Dvl-3 downregulation and gefitinib may be associated with p-GSK3 $\beta$. However, the precise function of GSK $3 \beta$ in EGFR and Wnt signaling pathways in mesothelioma cells requires further elucidation.

In NSCLC, Wnt signaling protects cells from EGFR-TKIs via tankyrase or $\beta$-catenin (13-16). An interaction between EGFR and Wnt signaling has been identified $(22,23)$. Numerous studies reviewed in Paul et al (22) have demonstrated that downregulation of $\beta$-catenin leads to a decreased expression of EGFR, signal transducer and activator of transcription 3, cyclin D1, matrix metalloproteinase (MMP)2, MMP9 and protein kinase B. In mesothelioma cells, Wnt signaling and EGF signaling pathways may support each other against cytotoxicity.

Dvl proteins relay Wnt signals from receptors to downstream effectors, which activate either the canonical Wnt pathway or the $\beta$-catenin-independent non-canonical pathway, depending on the nuclear translocation of $\beta$-catenin (24). Previous studies have reported that the suppression of Dvl inhibits the viability or tumorigenesis of mesothelioma cells (3-7), and the cell viability of lung cancer (4). Furthermore, our previous studies demonstrated that mesothelioma cells express Dvl-3 and that the inhibition of Dvl-3 suppressed mesothelioma cell viability, including that of $\mathrm{H} 28$ cells, which do not express $\beta$-catenin $(8,17)$. This suggests that the activation of Wnt signaling in mesothelioma cells may utilize the $\beta$-catenin-independent non-canonical pathway. Zhao et al (25) demonstrated that Dvl-3 induced upregulation of p120-catenin, which is associated with cell viability, invasion and metastasis of lung cancer. In lung cancer cells, cytosolic transmembrane protein 88 was revealed to interact with Dvl family members independently of $\beta$-catenin, which promoted invasion and metastasis by activating p38-GSK3 $\beta$-Snail signaling (26).

The underlying molecular mechanism that led to these results may be attributed to a reciprocal interaction of the EGFR and Wnt signaling pathways. The function of Dvl-3 may differ among cell lines utilizing the canonical and non-canonical pathways. Notably, $\mathrm{H} 28$ cells do not express $\beta$-catenin, which is suspected to be associated with a different signaling pathway from those utilized by other mesothelioma cells. Although Dvl-3 is unable to affect EGFR directly in H28 cells, downregulation of Dvl-3 may inhibit other pathways to compensate for the negative effect induced by inhibition of the EGFR pathway in H28 cells. However, in order to fully understand these mechanisms, further studies are required. Furthermore, the mechanism of cross-talk between these pathways in mesothelioma cells remains to be elucidated.

\section{References}

1. Vogelzang NJ, Rusthoven JJ, Symanowski J, Denham C, Kaukel E, Ruffie P, Gatzemeier U, Boyer M, Emri S, Manegold C, et al: Phase III study of pemetrexed in combination with cisplatin versus cisplatin alone in patients with malignant pleural mesothelioma. J Clin Oncol 21: 2636-2644, 2003.

2. Zhan T, Rindtorff N and Boutros M: Wnt signaling in cancer. Oncogene 36: 1461-1473, 2017.

3. Uematsu K, Kanazawa S, You L, He B, Xu Z, Li K, Peterlin BM, McCormick F and Jablons DM: Wnt pathway activation in mesothelioma: Evidence of dishevelled overexpression and transcriptional activity of $\beta$-catenin. Cancer Res 63: 4547-4551, 2003.

4. Uematsu K, He B, You L, Xu Z, McCormick F and Jablons DM: Activation of the Wnt pathway in non small cell lung cancer: Evidence of dishevelled overexpression. Oncogene 22: 7218-7221, 2003.

5. He B, You L, Uematsu K, Xu Z, Lee AY, Matsangou M, McCormick $F$ and Jablons DM: A monoclonal antibody against Wnt-1 induces apoptosis in human cancer cells. Neoplasia 6: 7-14, 2004.

6. You L, He B, Xu Z, Uematsu K, Mazieres J, Fujii N, Mikami I, Reguart N, McIntosh JK, Kashani-Sabet M, et al: An anti-Wnt-2 monoclonal antibody induces apoptosis in malignant melanoma cells and inhibits tumor growth. Cancer Res 64: 5385-5389, 2004.

7. Fujii N, You L, Xu Z, Uematsu K, Shan J, He B, Mikami I, Edmondson LR, Neale G, Zheng J, et al: An antagonist of dishevelled protein-protein interaction suppresses $\beta$-catenin-dependent tumor cell growth. Cancer Res 67: 573-579, 2007.

8. You L, He B, Uematsu K, Xu Z, Mazieres J, Lee A, McCormick F and Jablons DM: Inhibition of Wnt-1 signaling induces apoptosis in $\beta$-catenin-deficient mesothelioma cells. Cancer Res 64: 3474-3478, 2004.

9. Stewart DJ: Wnt signaling pathway in non-small cell lung cancer. J Natl Cancer Inst 106: djt356, 2014.

10. Lynch TJ, Bell DW, Sordella R, Gurubhagavatula S, Okimoto RA, Brannigan BW, Harris PL, Haserlat SM, Supko JG, Haluska FG, et al: Activating mutations in the epidermal growth factor receptor underlying responsiveness of non-small-cell lung cancer to gefitinib. N Eng1 J Med 350: 2129-2139, 2004.

11. Dazzi H, Hasleton PS, Thatcher N, Wilkes S, Swindell R and Chatterjee AK: Malignant pleural mesothelioma and epidermal growth factor receptor (EGF-R). Relationship of EGF-R with histology and survival using fixed paraffin embedded tissue and the F4, monoclonal antibody. Br J Cancer 61: 924-926, 1990. 
12. Govindan R, Kratzke RA, Herndon JE II, Niehans GA Vollmer R, Watson D, Green MR and Kindler HL; Cancer and Leukemia Group B (CALGB 30101): Gefitinib in patients with malignant mesothelioma: A phase II study by the cancer and leukemia group B. Clin Cancer Res 11: 2300-2304, 2005.

13. Casás-Selves M, Kim J, Zhang Z, Helfrich BA, Gao D, Porter CC, Scarborough HA, Bunn PA Jr, Chan DC, Tan AC and DeGregori J: Tankyrase and the canonical Wnt pathway protect lung cancer cells from EGFR inhibition. Cancer Res 72 : 4154-4164, 2012.

14. Fong JT, Jacobs RJ, Moravec DN, Uppada SB, Botting GM, Nlend $\mathrm{M}$ and Puri N: Alternative signaling pathways as potential therapeutic targets for overcoming EGFR and c-Met inhibitor resistance in non-small cell lung cancer. PLoS One 8: e78398, 2013.

15. Togashi Y, Hayashi H, Terashima M, de Velasco MA, Sakai K, Fujita Y, Tomida S, Nakagawa K and Nishio K: Inhibition of $\beta$-catenin enhances the anticancer effect of irreversible EGFR-TKI in EGFR-mutated non-small-cell lung cancer with a T790M mutation. J Thorac Oncol 10: 93-101, 2015.

16. Zhang Y, Zhang X, Huang J and Dong Q: Wnt signaling regulation of stem-like properties in human lung adenocarcinoma cell lines. Med Oncol 32: 157, 2015.

17. Uematsu K, Seki N, Seto T, Isoe C, Tsukamoto H, Mikami I, You L, He B, Xu Z, Jablons DM and Eguchi K: Targeting the wnt signaling pathway with dishevelled and cisplatin synergistically suppresses mesothelioma cell growth. Anticancer Res 27 4239-4242, 2007.

18. Jänne PA, Taffaro ML, Salgia R and Johnson BE: Inhibition of epidermal growth factor receptor signaling in malignant pleural mesothelioma. Cancer Res 62: 5242-5247, 2002.

19. Nutt JE, O'Toole K, Gonzalez D and Lunec J: Growth inhibition by tyrosine kinase inhibitors in mesothelioma cell lines. Eur J Cancer 45: 1684-1691, 2009.
20. Zheng H,Saito H, Masuda S, Yang X and Takano Y: Phosphorylated GSK3beta-ser9 and EGFR are good prognostic factors for lung carcinomas. Anticancer Res 27: 3561-3569, 2007.

21. McCubrey JA, Rakus D, Gizak A, Steelman LS, Abrams SL, Lertpiriyapong K, Fitzgerald TL, Yang LV, Montalto G, Cervello M, et al: Effects of mutations in Wnt/ $\beta$-catenin, hedgehog, notch and PI3K pathways on GSK-3 activity-diverse effects on cell growth, metabolism and cancer. Biochim Biophys Acta 1863: 2942-2976, 2016.

22. Paul I, Bhattacharya S, Chatterjee A and Ghosh MK: Current understanding on EGFR and Wnt/ $\beta$-catenin signaling in glioma and their possible crosstalk. Genes Cancer 4: 427-446, 2013.

23 . Hu T and Li C: Convergence between Wnt- $\beta$-catenin and EGFR signaling in cancer. Mol Cancer 9: 236, 2010.

24. Gao C and Chen YG: Dishevelled: The hub of Wnt signaling. Cell Signal 22: 717-727, 2010.

25. Zhao H, Zhao Y, Jiang G, Zhang X, Zhang Y, Dong Q, Luan L, Papavassiliou P and Wang E: Dishevelled-3 activates p65 to upregulate p120-catenin transcription via a p38-dependent pathway in non-small cell lung cancer. Mol Carcinog 54: E112-E121, 2015.

26. Zhang X, Yu X, Jiang G, Miao Y, Wang L, Zhang Y, Liu Y, Fan C, Lin X, Dong Q, et al: Cytosolic TMEM88 promotes invasion and metastasis in lung cancer cells by binding DVLs. Cancer Res 75: 4527-4537, 2015.

This work is licensed under a Creative Commons Attribution-NonCommercial-NoDerivatives 4.0 International (CC BY-NC-ND 4.0) License. 